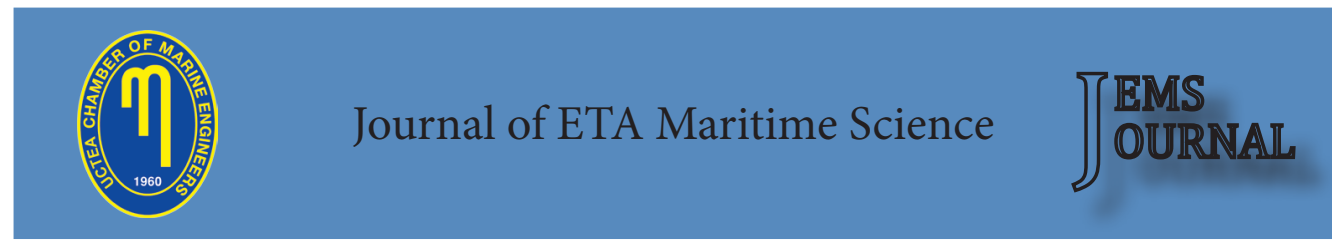

\title{
Turkish Republic of Northern Cyprus Vessel Traffic Services (TRNC- VTS)*
}

\author{
Serdar KUM ${ }^{1}$, Mehmet Emin DEBEŞ² \\ ${ }^{1}$ İstanbul Technical University, Maritime Faculty, aparlak@yildiz.edu.tr \\ ${ }^{2}$ University of Kyrenia, Maritime Faculty, mehmetemindebes@gmail.com
}

\begin{abstract}
The first Vessel Traffic Service (VTS) started in 1949 in the Liverpool Port (UK) and it continued in Netherlands in 1956. In Turkey, planning and management of the marine traffic using the waterways and ports in Turkey started with Turkish Straits VTS which came into service in 2003 due to the increase in traffic density enhance its effectiveness and necessity every year. Feasibility studies in five new areas have been initiated for the establishment of the VTS system by force of the strategic decision taken by the maritime authority in 2008. These areas are; Izmit Bay, Izmir Bay and Aliağa Region, Gulf of Iskenderun and Mersin. Monitoring the marine traffic has an important place as the Turkish Republic of Northern Cyprus (TRNC) is an important transition point in the Eastern Mediterranean region. For this reason, in this study the impact assessment and necessity of the establishment of a VTS to be located in the TRNC were evaluated by using Environmental (PEST: Political, Economic, Social, Technological) and SWOT (Strengths, Weakness, Opportunities, Threats) Analyses. In addition, the suitability of the possible locations of Traffic Monitoring Stations (TMS) has been examined by the field study. Evaluation of TRNC VTS in geographical and strategic terms will benefit from the opportunities and facilities that both the Republic of Turkey and the TRNC will have as a part of the effect of VTS against the embargo imposed on the TRNC in the world. Three appropriate VTS TMSs have been chosen as a result of the field study carried out for 10 determined TMSs; Cape Kormakitis, Cape Apostolos Andreas and Famagusta. It is also concluded that it would be appropriate to plan the Famagusta Station as VTS Centre. It is assumed to monitor and track the vessels in the zones out of the coverage area of these stations by Automatic Identification System (AIS). Safety and security in the shipping, protection of navigation, life, property and the marine environment of the region will be enhanced by monitoring the vessels passing particularly through this region and by making use of the opportunities provided by technology in accordance with national and international regulations.
\end{abstract}

Keywords: TRNC, VTS, PEST Analysis, SWOT Analysis

*An earlier version of this paper was presented at the $1^{\text {st }}$ National VTS Congress (8-9 December 2014, Istanbul) in Turkish. 


\section{Kuzey Kıbrıs Türk Cumhuriyeti Gemi Trafik Hizmetleri (KKTC-GTH)}

\section{$\ddot{O} z$}

1949 yılında ilk Gemi Trafik Hizmeti (GTH) Ingiltere'nin Liverpool Limanında başlayıp, 1956 yılında Hollanda'da uygulanmaya devam etmiştir. Türkiye'de ise gemi trafiğinin yoğunluğunun artması ile 2003 yılında hizmete giren Türk Boğazları GTH ile başlayan Türkiye'deki suyolları ve limanlarını kullanan gemilerin deniz trafiğinin planlanması ve yönetimi her geçen yıl etkinliğini ve gerekliliğini artırmaktadır. 2008 yılında stratejik kararlar gereği beş yeni alanda GTH kurulumu için fizibilite çalışmaları başlatılmıştır. Bu alanlar; İzmit Körfezi, İzmir Körfezi ve Aliağa Bölgesi, İskenderun Körfezi ve Mersin'dir. Doğu Akdeniz bölgesinde Kuzey Kıbrıs Türk Cumhuriyeti (KKTC)'nin konumu, önemli bir geçiş noktası üzerinde olması nedeniyle deniz trafiğinin izlenmesi önem arz etmektedir. Bu sebepten bu çalışma ile KKTC'de konumlandırlacak bir GTH sisteminin; Çevre (PEST: Politik, Ekonomik, Sosyal, Teknoloji) Analizi ile etki değerlendirmesi ve GZFT (Güçlü ve Zayıf Yönler ile Fırsat ve Tehditler) Analizi ile de gerekliliği değerlendirilmiştir. Ayrıca, saha çalışması yapılarak olası Trafik Gözetim İstasyonlarının (TGİ) yerlerinin uygunluğu irdelenmiştir. KKTC GTH'nin coğrafik ve stratejik açıdan değerlendirilmesi, dünyada KKTC'ye uygulanan ambargolara karşı GTH'nin etkisi ile hem TC hem de KKTC'nin sahip olacağı firsat ve olanakların değerlendirmesi gerçekleștirilmiștir. Araștırma sonucu 10 adet TGI için yapılan saha çalışması neticesinde 3 adet uygun GTH TGI belirlenmiştir; Kormacit Burnu, Zafer Burnu ve Gazimağusa. Gazimağusa İstasyonunun ayrıca GTH Merkezi olarak planlamasının yapılmasının uygun olduğu anlaşılmıştır. Bu istasyonların kapsama alanı dışında kalan bölgeler için de gemilerin izlenme ve takip edilmesinin Otomatik Tanımlama Sistemi (OTS) yardımı ile gerçekleştirilmesi öngörülmüştür. Özellikle bu bölgede geçiş yapan gemiler izlenerek ulusal ve uluslararası düzenlemelere uygun, teknolojinin sağladığı imkânlardan faydalanarak bölgenin seyir, can, mal ve çevre emniyet ve güvenliğini arttırılabilecektir.

Anahtar Kelimeler: KKTC, GTH, PEST Analizi, GZFT Analizi

\section{Introduction}

Cyprus is the third largest island in the Mediterranean after Sicily and Sardinia and it is located in the Eastern Mediterranean at the crossroads of the trade routes of three continents. The area of the Turkish Republic of Northern Cyprus (TRNC) is $3241.68 \mathrm{~km}^{2}$ and the total surface area of Cyprus is 9,251.50 $\mathrm{km}^{2}$. The closest neighbour country of TRNC is Turkey, which is located in $65 \mathrm{~km}$. Other neighbour countries are Syria (100 km), Egypt (420 $\mathrm{km}$ ) and Rhodes Island (480 km) [1]. Beş Parmak Mountains are located in the north of the TRNC between Kormakitis in the west and Cape Apostolos Andreas in the east in a width of 8-10 km and in a length of $170 \mathrm{~km}$. The highest point is "Selvili Tepe" (1024 m). When the TRNC is considered in terms of its location and characteristics, the strong and significant parts can be summarized as follows [2]:

- It has a long history and hosted great civilizations.

- The first trade and shipping in the history of civilization started in this region. (Today $30 \%$ of world trade and $25 \%$ of oil trade are carried out over the Mediterranean Sea).

- The centre of attraction of the great civilizations was this region and Cyprus has always been in the forefront.

- It is located at the crossroads of the trade routes of east and west

- High hydrocarbon resources are located on the seabed.

In addition, for Turkey, it has a special importance depending on the potential of 
the agricultural industry and the export of water resources with South Eastern Anatolia Project (GAP) in terms of having the nearest potential port bases and in terms of the routes of Baku-Tbilisi-Ceyhan (BTC) and Kerkük-Yumurtalık pipelines. When the distance to Turkey is considered, the distance between Cape Anamur and Cape Kormatikis is $45 \mathrm{~nm}$ and the distance between the furthest southern border of Turkey and Cape Apostolos Andreas is $67 \mathrm{~nm}$. In recent years, depending on the developments in Turkey, the need for Vessel Traffic Services (VTS) based on the marine traffic in this region has clearly emerged in converting Iskenderun Bay into a regional economy and logistics centre of attraction. Furthermore, VTS will make indisputable contributions to the increase of the dominance of Turkey in the maritime jurisdiction areas in the Eastern Mediterranean. With this purpose, Mersin VTS area is considered to be expanded. However, while this case involves many positive effects, the most important negative effect will appear as violation of authority in terms of international state policies. VTS will also have many effects on maritime security and military in addition to the contributions it will make towards shipping.

\section{Maritime Safety around Cyprus Island}

Cyprus is under the influence of Mediterranean Climate. Summers are hot and dry, winters are mild and little rainy. While the annual rainfall in the lowland areas is $300 \mathrm{~mm}$, it reaches $1000 \mathrm{~mm}$ per year in Troodos Mountains. Temperature rarely falls below $0^{\circ} \mathrm{C}$ [1]. Vegetation is maquis formed of small bushes. People living in villages deal with agriculture, viticulture and grow citrus. In addition to wheat and barley, oranges, mandarins and grapes on the outskirts of the mountains are cultivated. The most common forest tree species are; pine, cypress, oak and ash. More recently, eucalyptus trees were also planted. The island is considered in the
Taurus system of the Anatolian peninsula with the structure and the geographical landforms. Undersea pits which are deeper than $2000 \mathrm{~m}$ in the west and the south surround the base of the island, which is connected to Anatolia.

Cyprus is the accommodation and waypoints of birds between the continents of Africa and Europe due to its geographical location. 7 of around 350 species of animals on the island are endemic. In addition, 26 species of reptiles live on the island. In the ancient times, Cyprus was almost covered by wooded areas, but as wood has been sold to countries that lack copper mines and forests, forests have been destroyed today [1]. Cyprus coastlines have been visited by Chelonia and Carettacaretta turtles for approximately hundred million years. These creatures come to the beach of Northern Cyprus between May and August to lay eggs. Natural caves exist in the north of the island. There are around 85 natural caves including Incirli Cave with stalactites and stalagmites and Sutunlu Cave in Inonu Village.

Ports that are still active in the TRNC are [3][4]: Port of Famagusta, Kyrenia Tourism Harbour. In addition, the following are connected to Port of Famagusta in terms of inspection and technical services: Kalecik Fuel Filling Plants, Kalecik Plaster and Cement Plants, Altinbas Oil and Filling Plants, Aksa Power Generation Inc. The following are connected to Kyrenia Port: Teknecik Power Plant Fuel Filling Plants, Girne Marina, Gemyat Delta Marina, Gemikonagi Mines Pier, Kumkoy Water Filling Facility. The following fishing shelters connected to the Department of Ports due to their physical conditions are available in addition to the TRNC ports. There are fisheries in the Port of Famagusta, and other fishing shelters are named: Bogaz, Kumyali, Dipkarpaz (Şelonez), Efendiler, Yenierenkoy, Balalan, Kaplica, Tatlisu, Esentepe, Kyrenia Yacht and Fishing Shelter, Lapta, Kayalar, Yedidalga. Moreover, additional maritime services in TRNC are: 
pilotage, Cyprus Turkish Coastal Safety and Salvage Company Ltd., Cyprus Turkish Radio, North Cyprus Coastguard, etc. [3][4]. Figure 1 shows the marine traffic density in the Eastern Mediterranean Sea including the surrounding of the Cyprus Island.
Larnaca and Limassol VTS Centres provide both port and regional VTS services and attempt to control and manage the marine traffic in the region [6].

According to the $3^{\text {rd }}$ Working Document of EU Integrated Maritime Policies, in

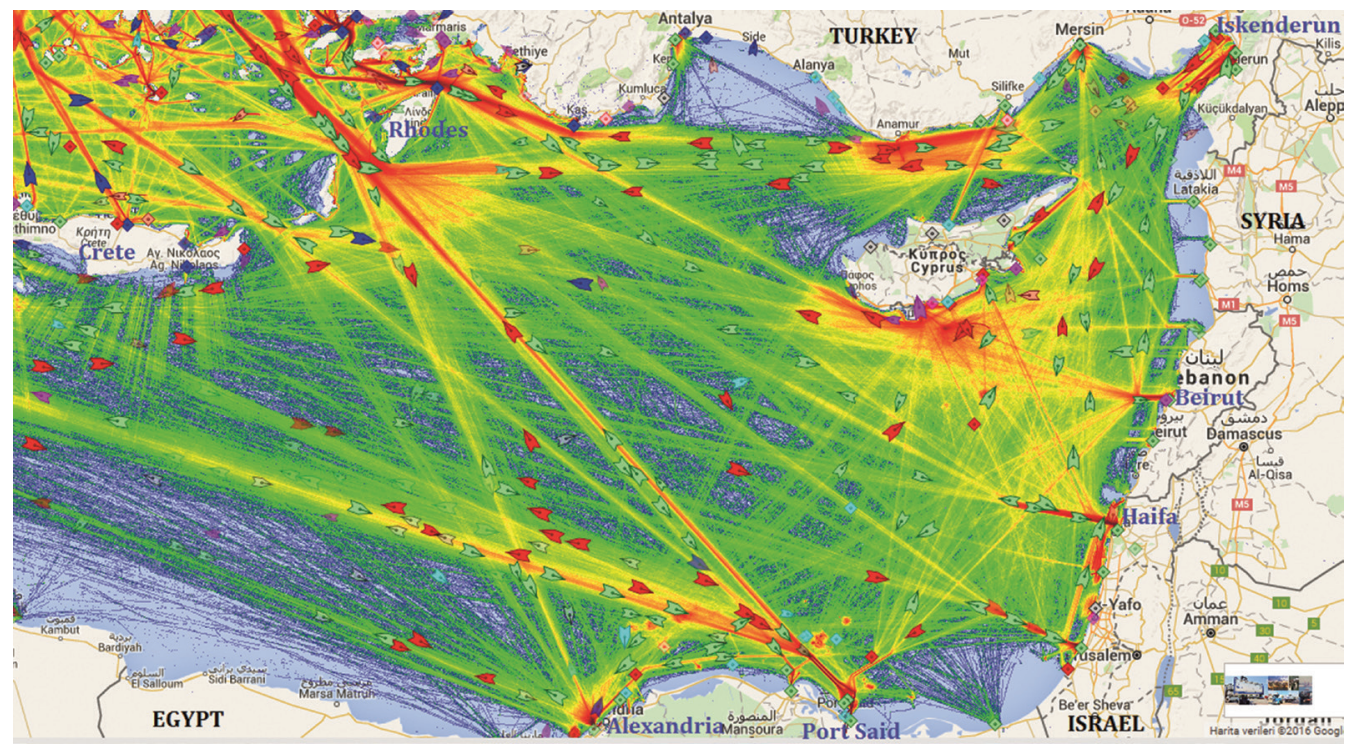

Figure 1. Marine Traffic in the Eastern Mediterranean Sea

Source: Marine Traffic (2016) [10]

\subsection{Existing Navigational Aids in the TRNC}

Lighthouses that ensure the coastal navigation safety provide services to the ships travelling around Cyprus at the international standard levels. All lighthouses except for Canbulat Lighthouse work with solar systems. Maintenance of lighthouses is executed by Cyprus Turkish Coastal Safety and Salvage Company [3] [4]. There are only 7 lighthouses (according to the Department of Ports, 12 port and shelter lighthouses are available) and 2 AIS receivers (Class B in Selvili Tepe, Kantara) in the TRNC [2].

\subsection{Southern Greek Cypriot} Administration: VTS and Navigational Aids

A large number of navigational aids both on the land and sea and eight AIS receivers are available in the Southern Greek Cypriot Administration [5]. In addition, Vasiliko, accordance with 2002/59/EC Directive and under the leadership of the European Maritime Safety Agency (EMSA), 10 member states in the Mediterranean (Portugal, Spain, France, Slovenia, Italy, Malta, Greece, Southern Greek Cypriot Administration, Bulgaria and Romania) established the "Regional AIS" cooperation networkin 2008. NATO led the establishment of this system and gave the management to Maritime Safety \& Security Information System (MSSIS); currently, Italian Navy Regional Virtual Marine Traffic Centre (V-RMTC) hosts this system. The system covers the entire Mediterranean [5]. It does not seem possible for Turkey to access this system without being an EU member and for the TRNC without agreeing for peace. For this reason, the traffic and environmental safety and security of the region can and should be ensured by establishing their own system by Republic of Turkey and the TRNC under cooperation. In the BORTEC (technical 
feasibility study of Southern Europe maritime border surveillance system) part of the same report, it was stated that Frontex conducted a comprehensive study in the second half of 2006. In this study, the existing maritime surveillance systems operator in Portugal, Spain, France, Italy, Slovenia, Malta, Greece and Southern Greek Cypriot Administration and the analysis of the operators were classified as confidential and public and extracted as a report. All the information in the report was named as Confidential and Limited [5]. As the final data regarding the report, data on Cyprus VTS are as summarized in Table 1. be once it is set up? How will it affect Turkey and the TRNC?" and some other questions was carried out on people who have a maritime background in the TRNC. When we consider the TRNC population and the number of experts on maritime, it is really restricted, and also people having similar interests know each other very well. So, all the people who took part in the survey are competent as Unlimited Ship Masters who graduated from Maritime Faculty, and are considered as experts who provided their opinions to the research question above. Brief information about the survey and study aim were included in the first part

Table 1. Responsibilities of Republic of Cyprus according to the 3rd Working Document of EU Integrated Maritime Policies

\begin{tabular}{|c|c|c|c|}
\hline \multicolumn{4}{|c|}{ Cyprus ACRS (Advance Coastal Radar for Surveillance) } \\
\hline Administration & \multicolumn{3}{|l|}{ Responsibilities } \\
\hline Police & \multicolumn{3}{|c|}{ Territorial Waters Patrol and adjacent High seas, Radars } \\
\hline Port Authority & \multicolumn{3}{|l|}{ VTS } \\
\hline Marine Trade Department & \multicolumn{3}{|l|}{ AIS } \\
\hline Department of Aquaculture & \multicolumn{3}{|l|}{ VMS } \\
\hline System & Administration & Purpose & Cross Linkage \\
\hline $\begin{array}{l}\text { Coastal Radar: ACRS } \\
\text { Additional AIS }\end{array}$ & $\begin{array}{l}\text { Radar: Naval Forces } \\
\text { AIS: Marine Trade } \\
\text { Department }\end{array}$ & Law force & $\begin{array}{l}3 \text { administrations are } \\
\text { included: Armed Forces, Police } \\
\text { (other user administration), } \\
\text { Marine Trade Department }\end{array}$ \\
\hline VTS & $\begin{array}{l}\text { Local port authorities } \\
\text { Marine Trade } \\
\text { Department } \\
\text { (AIS receivers) }\end{array}$ & Traffic monitoring & $\begin{array}{l}2 \text { administrations are } \\
\text { included: Port authorities, } \\
\text { Marine Trade Department }\end{array}$ \\
\hline VMS & $\begin{array}{l}\text { Department of } \\
\text { Aquaculture, Nicosia }\end{array}$ & $\begin{array}{l}\text { Monitoring } 28 \\
\text { trawlers carrying the } \\
\text { flag of Cyprus }\end{array}$ & $\begin{array}{l}\text { Police can view the VMS on a } \\
\text { different display in the ACRS } \\
\text { system }\end{array}$ \\
\hline VTMIS & $\begin{array}{l}\text { Marine Trade } \\
\text { Department }\end{array}$ & $\begin{array}{l}\text { Traffic monitoring, } \\
\text { gathering data, } \\
\text { distribution to } \\
\text { the relevant } \\
\text { administrations }\end{array}$ & $\begin{array}{l}\text { Integration of ACRS and } \\
\text { VTS. Providing data to } \\
\text { Police, SSN, JRCC and other } \\
\text { administrations when } \\
\text { necessary }\end{array}$ \\
\hline Patrol & Police & Patrol & \\
\hline
\end{tabular}

Source: European Commission-Joint Research Centre (2008) [5]

\section{Methodology}

\subsection{Survey Study and Subjects}

A survey study including the research question "Should a VTS be set up in the TRNC according to your opinion? How will its management be and what will its effects of the survey; the opinions on the research question were also included in the first part that was followed by the Environmental (PEST) Analysis. The authors aimed not to declare the participants in this sense, and only two questions were designed to get 
demographic information; one is "working in which organization/sector" and other is "duty/task". Furthermore, the authors carried out the questionnaire (PEST and SWOT Analyses) by using face-to-face interviews (and all of them were known very well by the authors).

In the end, data obtained from 15 experts (who have maritime background) were compiled for PEST Analysis, and then Strengths Weaknesses Opportunities Threats (SWOT) Analysis was conducted as the second survey practice and was applied on the same group. That's why, the authors used the face to face interview with all participants and the participants who involved in PEST survey were the same for SWOT survey.

Initially, the survey was planned to be applied on more than 50 people. It was delivered to both the government offices and civil institutions and organizations related to maritime activities in the TRNC (many of them do not have any maritime background but they were employed in maritime field). However, few people who have knowledge (due to their maritime background) to fill in the survey returned back and unfortunately many of them did not fill in the survey.

\subsection{Research Limitations}

The Environmental (PEST) Analysis form arranged for this study was filled in by conducting one-to-one interviews with 15 Oceangoing Ship Masters (Unlimited) who graduated from Maritime Faculty and live in the TRNC. Data obtained after the practice of PEST analysis were adapted for the SWOT analysis and a second survey was prepared that included the research question. All the people with maritime background employed in the TRNC were demanded to provide their views. Only 15 of them provided their views from the same group.

\subsection{PEST Analysis}

Environmental analysis is an analysis to find out issues that are significant, to warrant immediate action and reveal those who are positively or negatively affected by these factors by analysing Political, Economic, Social and Technological (PEST) factors. Environmental analysis is specially conducted before the SWOT analysis. PEST Analysis is an analysis that allows us to investigate the environmental factors around us and demonstrates what the environment is and will be in a Political, Economic, Social and Technological sense that we use in defining their effects on [7].

In the 1980s, many authors including Fahey, Narayanan, Morrison, Renfro, Boucher, Mekke and Porter used different abbreviations such as PEST, PESTLE, STEEPLE, etc. in their articles. However, any priority of any format or grading does not exist. The abbreviation PEST is known to be more popular than the abbreviation STEP. Some purists claim that the abbreviations STEP or PEST contain more appropriate titles for all cases, whereas others claim that there is a need for other titles for the external environmental analysis. PEST analysis is also called PESTLE (Political, Economic, Social, Technological, Legal, Environmental) with a wider content, and different types of analysis are available depending on its different names [8]. The stages of PEST analysis can be defined as introduction (stage of the preparation for analysis), determination of the market, determination of the subject of analysis (discussion of objectives and results), determination of the type of analysis, determination of analysis factors, conducting analysis (notes, potential effects, probabilities and severity ratings are determined). The next stage is the transfer of the analysis results to SWOT table [8].

\subsection{SWOT Analysis}

PEST Analysis is important in terms of balancing the SWOT Analysis internal factors, and their external factors against the environmental factors [8]. The most important characteristic of the SWOT 
analysis is that it allows a deeper evaluation by using the opportunities and strong points and it allows minimizing the weak points that it defines against the threats. SWOT analysis contains the examining of the environmental factors, the identification of important opportunities for the future of the business, taking precautions against the activities that can be a threat for the business by pre-defining them, the emergence of the strengths of the business and the identification of the cases, conditions and environments that they will be necessary to use, taking precautions by determining the weak sides of the business, the analysis of the difficult conditions that the enterprise can experience against the threats due to its weak sides and strategically, planning approaches [8].

\subsection{Results of PEST and SWOT Analyses}

The common idea of the experts is particularly the setting up of a VTS system in the TRNC. There is also an agreement on the selection of the location of the watchtowers. There is a disagreement on whether the management of the VTS Centre should belong to or be under control of Turkey or TRNC. Certain experts believe that if the towers are located at higher locations, the coverage area would increase but some of them believe that the setting up in this type of places will not be effective due to the factors such as maintenance. On the other side, a majority states that the management should belong to Turkey and some of them insist that the management should belong to Turkey or support should be provided by Turkey in terms of human resources and first operation of the system. Environment Analysis results are shown in Table 2 [2].

Table 2. PEST/PESTLE Analysis Evaluation Table

\begin{tabular}{|c|c|}
\hline Political & Economical \\
\hline $\begin{array}{l}\text { - The effect of the Southern Greek Cypriot } \\
\text { Administration on the orientation of the marine } \\
\text { traffic in the Eastern Mediterranean will } \\
\text { decrease, so this would cause an advantage for } \\
\text { the agreement. } \\
\text { - It will constitute a positive message to the } \\
\text { international community. } \\
\text { - There may be a pressure factor. } \\
\text { - It can create positive thoughts in other countries } \\
\text { - } \quad \text { The a country where embargo is implemented. } \\
\text { - } \quad \text { It can be effective for the recognition. } \\
\text { - International relations may develop. } \\
\text { - It can constitute an obstacle to inhibition of the } \\
\text { Southern Greek Cypriot Administration. }\end{array}$ & $\begin{array}{l}\text { - Increase in the work fields. } \\
\text { - The development of the maritime sector. } \\
\text { It will create opportunities for the TRNC } \\
\text { maritime transportation, } \\
\text { - It may lead to an indirect increase in the } \\
\text { economy. } \\
\text { - Development of the economy of the region and } \\
\text { sectors. } \\
\text { It may cause an increase in the economical } \\
\text { investments and reliability. }\end{array}$ \\
\hline Social & Technological \\
\hline $\begin{array}{l}\text { - The number of companies operating in the } \\
\text { maritime sector may increase. } \\
\text { TRNC public is very sensitive against } \\
\text { contamination of marine coastal environment. } \\
\text { Protection of the marine coastal environment } \\
\text { will be satisfied once the VTS is set up. } \\
\text { - Monitoring of environmental contamination. } \\
\text { - Maritime tourism and its positive effects on the } \\
\text { maritime culture. }\end{array}$ & $\begin{array}{l}\text { - } \quad \text { Formation of more modern and safe ports. } \\
\text { Positive contribution towards the search and } \\
\text { - } \quad \text { Increase in the technology transfers. } \\
\text { - } \quad \text { Monitoring of marine traffic in international } \\
\text { standards and in all environmental conditions. }\end{array}$ \\
\hline
\end{tabular}


Results of the SWOT analysis are shown in Table 3. The results obtained for the VTS system to be set up in the TRNC as a result of these assessments are;

- Setting up two watchtowers (the infrastructure is available in both places, all the necessities can be fulfilled regarding the infrastructure including the maintenance) as high as possible in the eastern and western capes (Cape Apostolos Andreas and Cape Kormakitis) within the borders of TRNC.

- There should be a system that will include marine ports (Famagusta and Kyrenia Ports).

- It is suggested to set up the towers on highlands in order to improve the coverage areas (it will contain more difficulties compared to other suggestions due to the infrastructure and maintenance).

- The middle of the Northern part as it is an alternative place (currently the area where the water and electricity pipeline that will come from Turkey is placed).

Table 3. SWOT Analysis Evaluation Table

\begin{tabular}{|c|c|}
\hline Strong sides & Opportunities \\
\hline $\begin{array}{l}\text { G1: Geography } \\
\qquad \text { G1.1 Location/Position } \\
\text { G1.2 Land conditions } \\
\text { G1.3 Meteorological conditions } \\
\text { G2: Strategically Importance }\end{array}$ & $\begin{array}{l}\text { F1: International Recognition } \\
\text { F2: Regional Marine Traffic Control (formation of } \\
\text { traffic lines, acceptability by IMO) } \\
\text { F3: Technological development } \\
\text { F4: Employment (labour and economy) } \\
\text { F5: Growth of the volume of marine trade (port, } \\
\text { arriving ship, etc.) } \\
\text { F6: Economic (protection of submarine treasure) } \\
\text { F7: Maritime jurisdiction }\end{array}$ \\
\hline Weak Sides & Threats \\
\hline 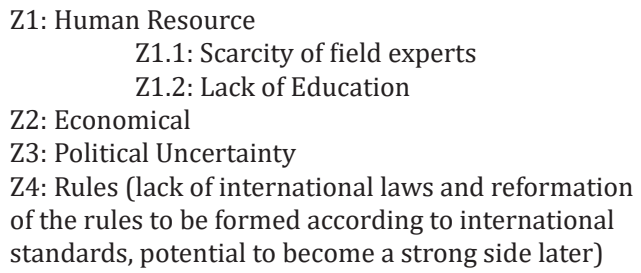 & $\begin{array}{l}\text { T1: Political Structure } \\
\text { T2: Organizational } \\
\text { T2.1 Prejudgements } \\
\text { T2.2 Bureaucracy } \\
\text { T2.3 Lack of coordination } \\
\text { T3: Neighbour countries } \\
\text { T4: Refugee movements in the region }\end{array}$ \\
\hline
\end{tabular}

\section{Source: Authors}

According to a majority of opinions, VTS Centre should be placed in Famagusta, and for others it should be in Kyrenia. On the other hand, such a centre should be in
Turkey, and Turkey should carry out the system operation until the development in human resources and field experts occur.

\subsection{Field Work: Determining Location for TMS and VTS Centre}

The process of determining TRNC-VTS Centre and Traffic Monitoring Stations (TMSs) after the survey evaluations, expert opinions and pre-studies is as follows; the preliminary meeting on the "Enlargement of VTS Eastern Mediterranean (Cyprus)" was held on 20-24 April in 2015 under the auspices of the Ministry of Transport, Maritime Affairs and Communications and Republic of Turkey in cooperation with related parties in the TRNC. Factors to be taken into account when determining the VTS Centre and TMSs are:

a. Size of the area to be monitored and technical facilities and system capability regarding monitoring,

b. Factors such as Traffic Separation Scheme (TSS), iron locations, reporting, etc. 
e. Environmental sensitivity,

f. Meteorological and hydrological factors,

g. Sensitive political situation in the Aegean Sea,

h. Political sensitivities in the East Mediterranean.

A study was conducted primarily on the map for the purpose of determining the TMSs to be set up. In addition, the Feasibility Commission considered that it is needed to understand marine traffic in Cape Apostolos Andreas and Port of Famagusta as well as Kyrenia Tourism Harbour. And also, TMSs should provide some advantages to improve safety of navigation as well as security of the water and fibre lines. The Feasibility Commission is divided into two groups as technical and operational; discoveries and observations have been made in the fields where TMS will be set up in technical terms and in the Directorates of Famagusta and Kyrenia Tourism Ports in operational terms. All the field research has been evaluated in accordance with the TMS Location Selection Form which includes the following information;

1. Field Name

2. Information about field (Public, Private, etc.)

3. Coordinates

4. Altitude Information

5. Information on Energy Infrastructure (information on electricity infrastructure and its transmission)

6. Information on Communication Infrastructure (fibre optic for around 2Mb)

7. Photography $\left(0^{\circ}-360^{\circ}-30^{\circ}\right)$

8. Notes on field

Feasibility commission investigated and filled in the TMS Location Selection Form for the following fields; Cape Kormakitis, Famagusta Port Zone (together with Coastguard Port Watchtower), Teknecik Powerplant, Cape Apostolos Andreas (together with Karpaz GSM Towers), and Sadrazam Village. As a result of field work, proposed TMSs are shown in Figure 2 including radar coverage zone (approximately $20 \mathrm{~nm}$ ).
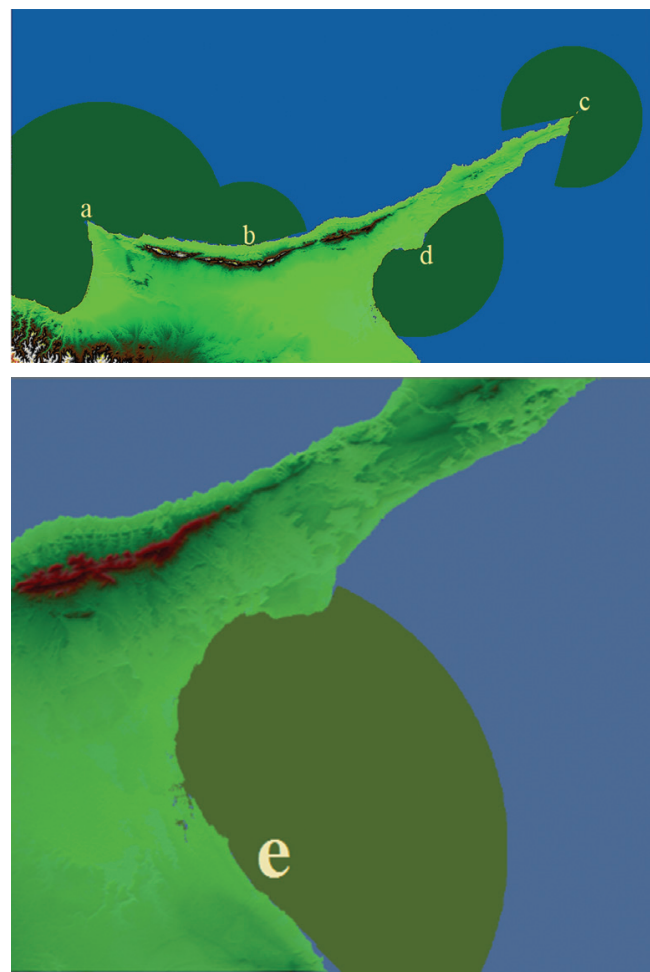

Figure 2. Radar Coverage Range; a. Sadrazam Village, b. Teknecik, c. Cape Apostolos Andreas and d. Zeytinlik Lighthouse, e. Famagusta (about $20 \mathrm{~nm}$ )

\section{Source: [Authors]}

\section{Proposed TRNC-VTS}

If a VTS will be set up at anywhere, the planning at the first stage should be evaluated at the following four stages according to the international rules (such as IMO, IALA, IAPH, IMPA, etc.)

a. Initial evaluation: This evaluation contains the research on whether an active traffic method is a convenient solution for the determined problems of the marine traffic and the initial risk analysis.

b. Feasibility and design: The aim here is to define the necessary system functions to reach the marine traffic, safety and efficiency level.

c. Risk evaluation: It is confirmed that the system with the defined functions and the other precautions to be taken will decrease the accidents and/or dangers 
within the scope of the intended level.

d. Cost-benefit analysis: It is defined whether the reductions are calculated at the risk level with the setting up of the system, and the decision is made.

\subsection{Aim of TRNC-VTS}

The aim of the VTS system to be set up in the TRNC is to increase the safety and security of the marine environment by taking into account the environmental factors rather than arranging the marine traffic. In addition, its other duties are the following: monitoring, providing information, assistance (navigation, search and rescue and related units), preventing accidents, protecting, and traffic management, strategic planning/practice. The expectation from TRNC-VTS as a "Coastal and Regional VTS" consists of the following:

- To improve the marine traffic safety and efficiency and to protect the marine environment against the negative effects of the marine traffic,

- To create an ideal awareness on marine environment at a national level especially in the Aegean and the Eastern Mediterranean,

- To support the efficiency of this system by transferring all the necessary data for the Vessel Traffic Management System,

- To create a safer and more efficient traffic structure for passengers, large and deep draft vessels,

- To follow the in-port actions in coordination with the Directorates of Ports (mooring, departing, shifting, anchoring actions, etc.),

- To be in more interaction with local passenger vessels,

- To contribute to more efficient work of the vessel and port plants in the port regions (anchoring, non-anchoring, mooring-departure planning, etc.).

- To make positive contribution to the quality and efficiency of the replenishment services (fuel, water, food, etc.) in the region.

\subsection{Organizational Structure of TRNC- VTS}

The staff of TRNC-VTS might be kept at a minimum amount in the beginning. As the public governance of the TRNC is too cumbersome, it is recommended to establish it as a State Economic Enterprises managed by a Directorate with a fast working decision-making mechanism. The name of this Directorate should be "Vessel Traffic Services Directorate" and should be inspected by the Directorate of Ports.

In technical and operational terms, a structure consisting of two assistants working with a shift system where each shifts will contain 2 Operators (one Supervisor and one Operator) formed of 4 shifts is recommended. In this case, the total number of employees is 14 (1 Director, 2 Deputy Directors (Operation-Technical), 4 main Operators and 4 Operator, HardwareSystem-Information Engineers). For example; features of staff to work as a VTS operator are specified in [9].

\section{Conclusions}

This research presents a VTS system to be set up in the TRNC. As a result of the field work and the authors' proposal, TRNCVTS should be established with only three TMSs, as shown in Figure 3. The regions outside the coverage area of the radar must be equipped with AIS stations so as to cover the entire coast as shown in Figure 4, as the radar coverage of the entire coast of the TRNC is not possible.

The contributions that will be made by VTS to be set up in the TRNC are indisputably acceptable according to the gathered data. It is estimated that ensuring the most effective way of establishing this is by setting up three TMS in Cape Kormakitis, Cape Apostolos Andreas and at the location of Zeytinlik Lighthouse or at a convenient location at the Famagusta Port. It is also anticipated that AIS will monitor the regions out of the coverage of these three radars and this will be carried out by the VTS Operators to be employed in the VTS Centre to be 


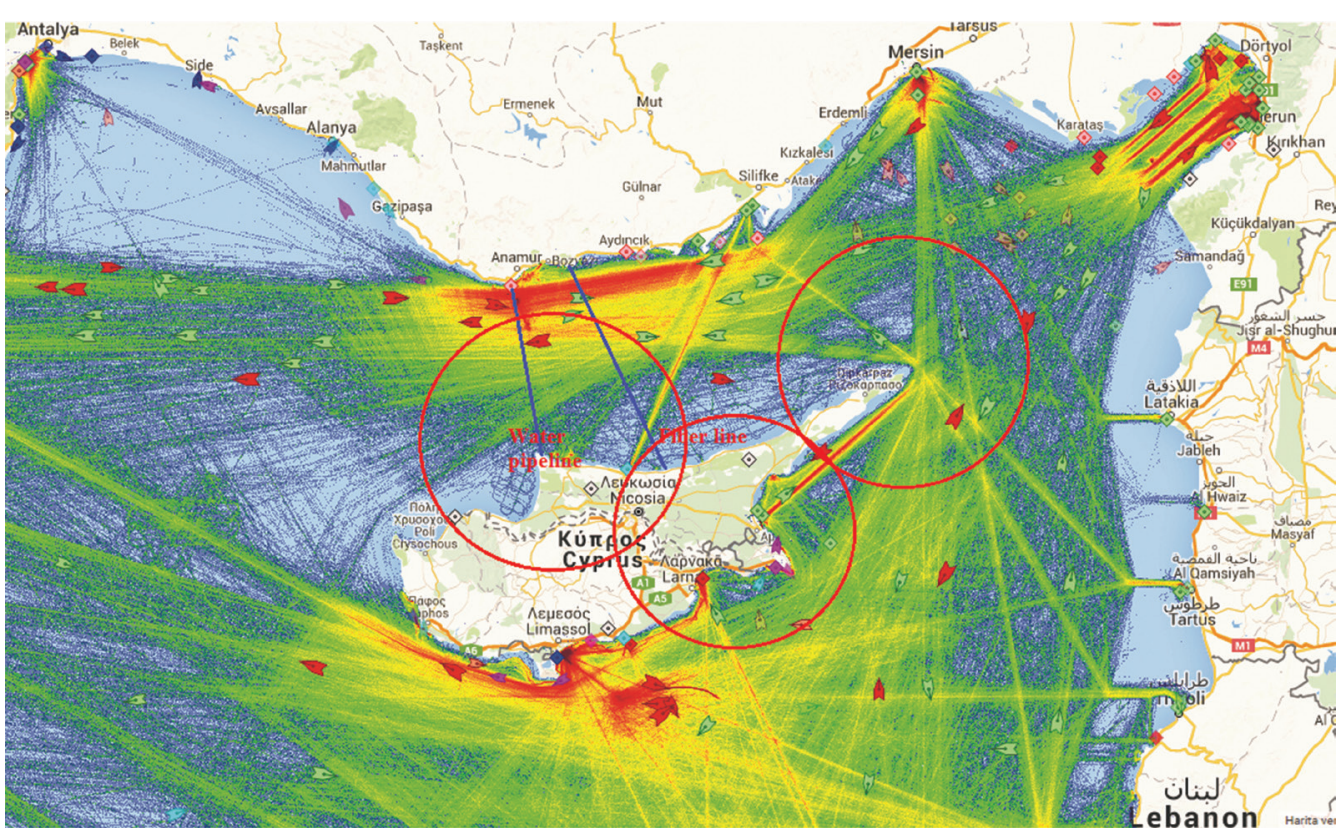

Figure 3. Fields Determined for the Radar Coverage (Red circles presents around $20 \mathrm{~nm}$ ) and TMS RLcations on Vessel Density Chart (Blue lines are; water pipeline and fiber line)

Source: Marine Traffic (2016) [10]
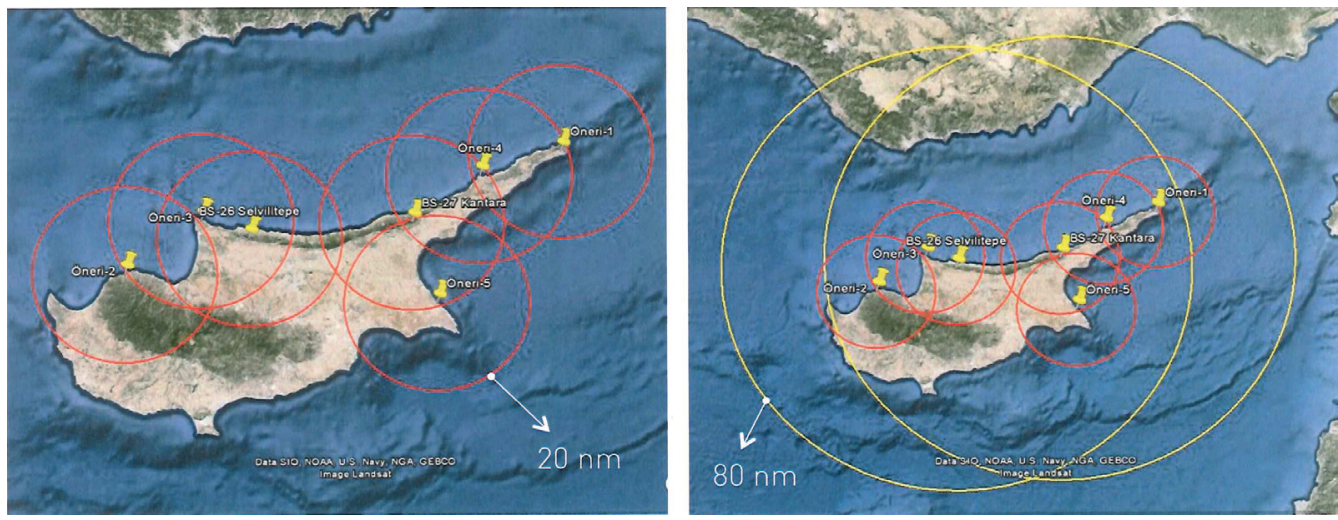

Figure 4. Planned AIS Stations and Their Coverage Areas

established in the TRNC (in Kyrenia and/or Port of Famagusta).

The main aim of TRNC-VTS will be the protection and monitoring of the environment rather than monitoring and planning of the vessel traffic. When the vessel traffic around is considered, this level of density may not require the setting up of a VTS, but as an island country which makes tourism a basic stone of the economy, protection of the environment and prevention of the marine pollution come into prominence. Another reason for this is that TRNC maritime and marine environment will become stronger in case of the human trafficking due to the recent political instability in the Middle Eastern countries and in the event that an agreement is made as a result of the negotiations between the TRNC and Southern Greek Cypriot Administration.

TRNC-VTS to be installed is very significant, as it will enrich the statistical information regarding the maritime. It is believed that the transfer of the wakes to be obtained from the TMS to Mersin VTS 
Centre over the network infrastructure, subjecting them to a wake fusion and the transfer of the obtained image to the TRNC over the network would be convenient. It is obvious that the information and data sharing between VTS Centre in the TRNC and Turkey will be available. The political and strategic long-term national benefits should be considered in addition to the short-term technical and operational benefits while taking these decisions. It also has an important place for other issues that require the consideration of the political balance that will especially appear in a wider range apart from the constant effects. In conclusion, the expectations from TRNC-VTS can be summarized as follows:

- To play the role of a regional VTS as well as a coastal VTS for the TRNC port and marine borders,

- To improve the safety and efficiency of the marine traffic in Turkey, the TRNC and the region,

- To protect the marine environment,

- To create an awareness on the marine environment at a national/ international level in the Eastern Mediterranean,

- To enable the data transfer between Turkey and the TRNC and to support the efficiency of the vessel management system,

- To follow the port activities of the TRNC (mooring, departing, anchoring, etc.)

- To make positive contribution to the quality and efficiency of the replenishment services (fuel, water, food, etc.) in the region.

\section{Acknowledgements}

We would like to thank particularly to Capt. Okan ARI (on behalf of Navigational and Marine Safety Department, Ministry of Transport, Maritime Affairs and Communications) to Capt. Tuncay ÇEHRELI (Chairman of IALA VTS Committee), Capt. Burçin ERLEVENT, and Dr. Capt. Hasan TERZI who held the $1^{\text {st }}$ National VTS Congress, and all member of Feasibility Commission for sharing of information/ documents, their valuable comments, suggestions and precious supports.

\section{References}

[1] KKTC Turizm Tanıtma ve Pazarlama Dairesi (2016). Coğrafi Konum. Accessed: 15 October 2013, http:// ttpd.gov.ct.tr/

[2] Debeş, M.E., Kum, S. and Boşnak, T. (2014). KKTC'de GTH Sistemi Kurulmasına İlișkin Bir Çalışma (Turkish), In Proceedings of the 1st National Vessel Traffic Services Congress (I. Ulusal Gemi Trafik Hizmetleri Kongresi) (pp. 15-23), Istanbul: Istanbul Technical University and Maritime Traffic Operators' Assosication

[3] TRNC Ministry of Public Works and Transport (2013). Directorate of Department of Ports, Annual Report. http://bub.gov.ct.tr/Dairelerimiz.aspx

[4] KKTC Limanlar Dairesi Müdürlüğü (2013). Gazimağusa Liman Başkanlığı. Accessed: 10 February 2015, http://www.limanlar.gov.ct.tr/ LimanBa\%C5\%9Fkanl\%C4\%B1klar \%C4\%B1/Gazima\%C4\%9FusaLim anBa\%C5\%9 Fkanl\%C4\%B1\%C4\%9 F\% C4\%B1.aspx

[5] European Commission-Joint Research Centre (2008). Integrated Maritime Policy for the EU, http://ec.europa.eu/ maritimeaffairs/policy/integrated_ maritime_ surveillance/documents/ maritime-surveillance_en.pdf

[6] Vasiliko Terminal (2016). VTS Cyprus (Vasiliko). Accessed: 29 October 2014, http://www.vtsvasilikoterminal.com/

[7] Stratejik Yöntem (2015). PEST Analizi Tarihçesi. Accessed: 18 October 2014, http://stratejikyonetim.org/PESTanalizi-tarihcesi

[8] Tekno Sector (2015). PEST Analizi. Accessed: 18 October 2014, http:// teknosektor.com/2013/10/22/pestanalizi/

[9] Gemi Trafik Hizmetleri Sistemlerinin Kurulmasına ve İşletilmesine İlişkin 
Yönetmelik (2007). Resmi Gazete 18.02.2007, Say1: 26438.

[10] Marine Traffic (2016). Live Map. Accessed: 01 May 2016,m https:// www.marinetraffic.com/

[11] Tamçelik, S. and Kurt, K. (2014). Türkiye'nin Münhasır Ekonomik Bölge Algısı ve Yakın Tehdit Alanı: Kıbris. In Proceedings of the Uluslararası Güvenlik Kongresi Bildiriler Kitabı (3). Kocaeli Üniversitesi Yayınları.

[12] Başeren, S. H. (2011). Doğu Akdeniz Deniz Yetki Alanları UyuşmazlığıDispute Over Eastern Mediterranean Maritime Jurisdiction Areas. İstanbul: İlke Yayınevi

[13] Özel, Ç. and Erdoğan, M. Ş. (2014). East Mediterranean Energy Resources and Policy, Accessed: 29 October 2014, http://webcache.googleusercontent. co $\mathrm{m} / \mathrm{s}$ e arch ? q = c a che : a a U oSW_ZLkJ:www.erdoganhukuk. com/dosyalar/doguakdeniz. $\mathrm{docx}+\& \mathrm{~cd}=3 \& \mathrm{hl}=\mathrm{tr} \& \mathrm{ct}=\mathrm{clnk} \& \mathrm{gl}=\mathrm{tr}$

[14] Dogan, N. (2013). Energy Strategies in the Eastern Mediterranean and the Future of Regional Security. 21st Century Institute of Turkey, Accessed: 10 February 2015, http:// www. 21 yyte.org/tr/arastirma/ enerji-ve-enerji-guvenligi-arastirm alarimerkezi/2014/01/15/7383/ dogu-akdenizde-enerji-stratejileri-vebolgesel-guvenligin-gelecegi

[15] Vogler, S. and Thompson, E. V. (2015), Gas Discoveries in the Eastern Mediterranean: Implications for Regional Maritime Security, Policy Brief 